\title{
Alumni perceptions of a post graduate Information and Library Science Education programme at the University of Natal, South Africa
}

\author{
C.Stilwell \\ Information Studies, School of Human and Social Studies, University of Natal, Private Bag XOI, Scottsville, 3209. \\ Stilwell@nu.ac.za
}

Received: $26^{\text {th }}$ November 2002

Revised: $2^{\text {nd }}$ September 2003

A survey of alumni perceptions of a post graduate programme in Information and Library Science, the B. Bibl. Honours, at the University of Natal, South Africa is described. Module content and appropriateness are reviewed in relation to demands of the workplace. Alumni views on delivery and assessment methods are interrogated as are requirements in terms of continuing education. Critical issues in ILS education are identified, for example, balancing a human-centred approach with Information and Communication Technology competencies in the networked age. Reference is made to Information Management and Knowledge Management. Findings suggest that the Programme has broadly attained its anticipated outcomes in preparing alumni for the workplace and that to some extent a balance between the various considerations outlined in the literature had been achieved.

\section{Introduction}

This article describes a survey of alumni perceptions of a post graduate programme in Information and Library Science (ILS), the B.Bibl. Honours, at the University of Natal, Pietermaritzburg, South Africa. The aim of the survey was to investigate the extent to which the B.Bibl. Honours Programme was seen by its alumni to have achieved its desired outcomes. The survey is part of a larger tracer study planned for the University of Natal's Information Studies Programme. Following on Bell's 1998 study of the role of the Information Studies Department (as it then was) tracer studies of the various categories of alumni were planned. As a form of regional needs analysis feedback from alumni was regarded as important for programme review. Such feedback can indicate which aspects of formal professional training were useful or may become useful and also which areas need to be considered for inclusion in future curriculum revision. As co-ordinator of the B.Bibl. Honours programme the author embarked on the study reported in this article. A tracer study of the Post Graduate Diplomates is in progress.

\section{Background to the study}

In this section a brief review of the ILS education context in South Africa and the KwaZulu-Natal programmes are provided. The University of Natal and its Information Studies Programme are described last in this section, following a review of the literature. Themes and issues from the international and local literature including the literature on approaches to assessing ILS education are reviewed briefly to provide the theoretical context for the article.

Brief note on ILS education in South Africa and the KwaZulu-Natal programmes

Hart (2002:35) identifies I5 South African ILS departments. 3 of the ILS departments no longer offer education for librarians per se. Others dropped their specialist modules in children's literature, for instance, in the 1990s to make way for new ICT modules (Hart 2002:35). In KwaZulu-Natal the University of Zululand provides options from B.Inf. and B.Bibl. to Ph.D. and the offerings of the Durban Institute of Technology include a three year National Diploma, the B.Tech., M.Tech. and D.Tech.

Review of ILS education themes and issues in the international and local literature

In this section themes and issues from the international and local literature on ILS and ILS education that are perceived to be relevant to the article are examined. Two key elements in the literature are discussed before moving on to a review of literature on the South African ILS education landscape. Finally some sources from the literature on assessing ILS education are noted briefly.

Firstly, Dervin (1994), in the United States context, identifies as a core challenge the designing of user centred information systems which provide access to knowledge and communication channels. Dervin also recognises the centrality of the individual in the knowledge construction process thereby bringing into proximity, in the author's view, User Studies and Knowledge Management. The new Information and Communication Technologies (ICTs) are available to support the networks for these systems. Dervin's views link with the work of Snowden (2002), who at a recent Colloquium in Stellenbosch (Snowden 2003) again made the case for human-centred Knowledge Management. This approach, as does Dervin's earlier work on information seeking behaviour (1992), emphasises the centrality of sensemaking. Sensemaking is defined here as involving "processes of perceiving, believing, interpreting, explaining, 
predicting and acting both individually and collectively in a given organizational setting ... in which individuals develop cognitive maps of their environment" (Cecez-Kecmanovic and Dalmaris 2000:2). By studying sensemaking processes we can better understanding how individuals create shared meanings, how they create collective knowledge and how this knowledge is deployed.

Secondly a new vocationalist approach to ILS education has been censured in the United Kingdom (UK) for exhibiting an orientation to the labour market rather than to professional values based in public service (Muddiman 1994:267). The Information UK 2000 report of 1990 noted that there was likely to be ever increasing pressure for education for ILS curricula to be filled with information technology and retrieval at the expense of more human-centred aspects of the profession (Martyn, Vickers and Feeney 1990). These trends and that towards the inclusion of more generic skills in the curricula are seen as inclined to limit the operation of module elements with more critical goals (Muddiman 1994:267). Parker (2002) has raised concerns about this approach in the Higher Education context in South Africa. Snyman's (2000) paper, described below, however, suggests a resolution of some of the tensions around the new vocationalist approach, that is between educating ILS professionals and educating and training for the job market. Snyman's study shows that the requirements of the job market in South Africa are largely in harmony with those of the ILS authors and educators reviewed in this article, that is providing a sound base in the theory, inculcating critical and analytical skills, integrating theory with practice, having a human-centred approach and focusing appropriately on ICTs.

Concerning the South African ILS landscape, Snyman (2000:I) from her base at the University of Pretoria, identifies vast changes, due in part to the launching of new government initiatives such as the Government Communication Information Systems (GCIS). She notes that the globalisation of markets, the relaxation of trade restrictions and advances in ICTs are fostering a wider exchange of information among people. She identifies a move towards a knowledge-based economy in which the emphasis is on sharing knowledge so as to create new knowledge in organisations, hence the management of knowledge has become central. Developments in digital technology have brought changes in the delivery of information and the nature of collections with a shift towards electronic sources and digital libraries.

Snyman reports on a study in which she analysed the job advertisements for the three national newspapers with the highest circulation, from January to August in 1999. She found that of the 250 jobs involving a significant amount of information handling, II4 positions were potentially open to trained information workers (Snyman 2000:2). These positions included library workers, information workers, information systems specialists, information and knowledge managers, information analysts and research workers, advisors and consultants, records managers, archivists, teachers and trainers and managers of a library association (Snyman 2000:4). From the analysis of newspaper advertisements Snyman concludes that the advertisements supported the view that "the information worker possesses unique competencies" and that "a number of organizations acknowledge the advantages of appointing people with a sound knowledge of information handling/management" (Snyman 2000:15). In addition she notes that the advertisements appeared on various seniority levels that required varying qualification and experience levels. In 7 of the identified advertisements positions existed for information and knowledge managers who were responsible for the integration of information content management and information systems management. She makes a key point in stating that although some academic departments are phasing out their degrees in library science, "a large demand still exists for librarians. Of the 114 positions included in the study 35 (31\%) were for librarians" (Snyman 2000:15). She suggests that in all the instances reviewed a qualification in library and /or information science was regarded as of great value as a primary or additional qualification (Snyman 2000:16).

Snyman (2000:16-17) concludes on the basis of her study that ILS professionals need to have a sound theoretical background, good interpersonal and teamwork skills, the ability to think analytically and critically, and ICT competencies. The requirements outlined by Snyman suggest the challenges to educators in the ILS field in South Africa in balancing human-centred, theoretically rich modules with critical and analytical goals, with ICT-directed and more applied modules.

At the level of national education policy a major influence has been new accreditation procedures. The Department of Education is assisted by a statutory body the South African Qualifications Authority (SAQA) which was established to achieve equity and redress and improve the quality of education in the country. SAQA oversees the development of a National Qualifications Framework (NQF) by formulating and publishing the policies and criteria for the registration of bodies responsible for establishing education and training standards and for the accreditation of bodies for monitoring and auditing achievements. SAQA also oversees the implementation of the NQF and a criterion is that standards and registered qualifications are internationally comparable (Ocholla 2000:4I-2).

Noting some of the challenges presented in the South African ILS education environment, Ocholla $(2000: 37,46)$, from his base in KwaZulu-Natal, states that new thinking and a desire for managing change has led to collaboration where departments have been forced to merge, re-orient and diversify. Some have moved faster than others to manage change through programme review, achieve convergence by merging, admit foreign students and engage with the new ICTs. 
Ocholla offers a comparative review (2000) firstly of ILS education in Africa and then describes the curriculum response of the University of Zululand to a changing information environment (Ocholla 200I) such as that outlined by Snyman (2000), for instance. Ocholla (2001:166) confirmed findings in his earlier studies emphasising sound education in management, ICTs, information searching, analysis and synthesis, as well as the ability to do practical work. He defends the teaching of cataloguing and classification on the basis that they provide knowledge about the analysis and synthesis of information as well as knowledge of the nature and structure of a given collection. While integral to the library's role in ordering and managing information such knowledge and skills are also crucial for service to users. The emphasis on ICTs is important for opening up the potential of the networked library. Hence Ocholla, too, supports a user centred approach, recognition of the importance of theory, and integrating theory with practice and with ICT competencies.

Another relevant local ILS education issue, in the author's view, is Manaka's (1999:208) contention that African ILS services should take into account local socio-cultural and political problems. Kaniki (1994) explains that few local departments offer modules in rural librarianship but on the other hand, as Underwood and Nassimbeni (1999:194-5) sensibly contend, no single department is likely to have the capacity to span the full spectrum of programmes required. The need to prioritise and balance curriculum content was taken into account in the current study.

Among the ways to assess ILS offerings are students' and external examiners' evaluations. Other methods are described in studies of ILS education graduates and diplomates (Mhlongo 1998; Goulding, Bromham, Hannabuss and Cramer 1999; Ocholla 2000). The methods used in this particular programme at the University of Natal are described below.

The University of Natal and the Information Studies Programme

In addition to the Pietermaritzburg campus the University of Natal comprises Howard College, the Nelson R. Mandela School of Medicine and Edgewood College, all in the Etekweni Metropolitan Region. UN is in the process of merging with the University of Durban Westville.

The UN Information Studies Programme is based in Pietermaritzburg. Extracts from the mission of the UN programme, then the Department of Information Studies, at the time of the survey outline its key priorities. The Department aimed to:

- educate and train library and information workers from the first professional qualification to $\mathrm{PhD}$ levels, ... who are able to be perceptive, responsive and adaptive to the information requirements ofall South African, and indeed other African, countries and who may take the initiative in a re-oriented library and information system

- endeavour to function as a leader in the field of library and information ... by effective participation in library and information science researchand development

The Department commits itself to the importance of libraries and information in democratising society ... (University of Natal. Department of Information Studies. 1994).

While the emphases of the Programme have shifted over the nine years since this mission was written the key points about providing appropriate professional education and training, being cognizant of the local and regional context, equipping students for research endeavour, and being socially responsive, remain important and are reflected to varying degrees in the expected outcomes for the programme under review in this article (see the objectives of the study below).

Key themes from the literature review above, which build on the points raised in the mission statement and the module outcomes, have been used to inform this assessment. These themes include balancing a human-centred approach, for example, in Information Management (Remenyi, White and Smith 1997) and Knowledge Management (Orna 1999:I I; Snowden 2002) on the one hand and a use of Information and Communication Technologies appropriate to a networked age on the other; combining theory with practice, and inculcating analytical and critical skills.

The UN programme commenced with the post graduate diploma following on a Junior Degree in any field in 1973. This model for the first professional level has been retained by UN in the Post Graduate Diploma in Information Studies (PGDIS). UN provides a full suite of offerings starting with an undergraduate module in Information Literacy that acts as a feeder module for the PGDIS and is a core module in an access programme. The UN Programme has six lecturers.

The B.Bibl. Honours was provided for the first time in 1980. A Master's in Information Studies is offered by dissertation and by course work. The Doctoral programme attracts ILS personnel from various African countries. Other foci include the Diploma in School Librarianship, and Postgraduate Diplomas in Museum Studies and in Records and Archives Management. These offerings fit the pattern of the South African ILS system whereby an aspirant graduate has to complete five years of ILS education at a tertiary institution before admission to a Master's programme (Ocholla 2000:40). In recent years the UN Programme has articulated a route for students from the B.Tech. into the B.Bibl. Honours.

Some of the challenges described by Ocholla (2000) and Snyman (2000) have been positive for this Programme, for instance, being situated since 1999 in the re-configured Faculty of Human and Management Sciences as part of the School 
of Human and Social Studies along with other cognate disciplines has been enriching. New synergies have developed, for instance, in the offering of a School-wide module in Advanced Research Methods which is described in more detail below along with other examples.

\section{Aim and objectives of the study}

Both students' and external examiners' evaluations are mandatory in the UN programme. The survey described in this study was designed to capture another form of assessment, that is, the views of alumni from the workplace about which aspects of the professional educational programme were useful or could be in the future, hence its aim was to investigate the extent to which the B.Bibl. Honours programme was seen by alumni to have achieved its desired outcomes. As much of the history of the programme predates the NQF this assessment was partly retrospective. In terms of the NQF requirements modules are offered within programmes and both are structured around respective templates of desired outcomes with the module template detailing delivery and assessment methods.

The objectives of the study were, therefore, based on the Programme outcomes and were thus to establish whether the B.Bibl. Honours Programme

- had achieved its anticipated outcomes in further preparing studerts for the workplace, that is after the first professional level in the PGDIS and

- had provided students with the skills required for research endeavour in the workplace or in formal courses

- had particular strengths and weaknesses, and in what way curriculum content needed to be addressed

- had effective modes of delivery and

- had appropriate assessment methods.

Professionals as defined here take prime responsibility for defining and shaping the work task according to their own judgement (Muddiman 1994:263).

\section{Methodology}

In addition to a review of the relevant literature, the study used documentary sources from the programme such as the mission statement, module templates and alumni records. To a limited extent observation was used. The methods described were used in addition to the survey ${ }^{1}$ of alumni identified as having completed the requirements of the degree were 136 alumni. Of the III whose current work situation, were known 73 (66\%) worked in KwaZulu-Natal and 26 $(23 \%)$ in the Eastern Cape. The Western and Northern Cape yielded another one each (1\%) while Limpopo had two (2\%) and Gauteng five (5\%). The Southern African Development Community countries, Lesotho and Zimbabwe, had two (2\%) and one alumnus ( $1 \%)$ at this level respectively.

A questionnaire was designed to unpack the elements of the intended outcomes and to solicit responses to these elements. Questions asked were therefore based on programme outcomes, on issues identified in the literature and on the author's observations. Specific contact details were available for 100 alumni and they were mailed a copy of the survey in October 1999. An electronic-mail reminder in 2000 yielded another seven responses bringing the total to 40 ( $40 \%$ of the total surveyed but $29 \%$ of the population of 136). Data analysis compared alumni perceptions of outcomes with intended outcomes, thereby gaining insight into the programme. Data reduction and analysis of the responses to unstructured questions entailed content analysis. Frequencies and percentages were calculated for these and responses from structured questions. Where possible details of alumni comments were given to achieve a more qualitative approach.

Several modules had changed in name or content and new modules had been introduced over the years, hence generic categories were used to identify them. To see if respondents could remember some or all of the modules that they had studied, alumni were not provided with a list of modules but were asked to recall what they had studied. Some alumni could not remember all the modules they had completed.

\section{Findings}

This section describes findings concerning the year in which the degree was completed and number of years taken to complete; employment patterns; ratings of modules, delivery and assessment methods; research activity and further study since completing B.Bibl. Honours. General suggestions about improving the programme are reported as well as specific areas for further education and training. As the responses for the respondents' duties and the module ratings are scattered and the scores low, percentages are not given.

Year in which the degree was completed and number of years taken to complete

Of the respondents, 24 of $40(60 \%)$ gave the year in which they completed the B.Bibl. Honours programme with 12 (30\%) completing in 1997 and 1998 and a further 4 (10\%), in 1994. The balance was spread over the years 1990 to 1996. The higher response from more recent graduates was to be expected and they were also likely to have better recall 
about the modules which they had completed. Of the respondents $38(95 \%)$ answered the question about how many years they had taken to finish the degree and 21 (53\%) had taken two years. The programme was designed to accommodate working ILS personnel and as it is a popular option, this finding was to be expected. Another II (28\%) had taken I year full time to compete the programme with a small minority of $6(15 \%)$ taking 3 years or more.

Employment patterns

37 (93\%) had been employed in an information supplying agency of some sort. 21 (53\%), were still employed in such an agency. 16 (40\%) had been employed in an information supplying agency but were no longer employed in such an agency and $3(8 \%)$ had never worked in an information supplying agency at all. For those still in ILS, details are given below about the agencies, their location, time spent in these agencies, the nature of the position held by the respondents and their duties.

Type and location of agency

The employing agencies were academic libraries I5 (38\%), records and documents management units 2 (5\%), school libraries, provincial libraries, special libraries and education departments, all I (3\%). Of the 21 respondents still employed in such agencies 17 (43\%) were working in KwaZulu-Natal which was to be expected in view of the number of alumni located in this province. All 2 I worked in cities or towns thus suggesting Manaka's point (1999:208) about the lack of rural librarians.

Time spent and the nature of the position held by the respondents

The length of time spent in current positions ranged from I to 25 years. Of the respondents $9(23 \%)$, had spent $1-5$ years, 6 (15\%) 6-10 years and the rest had spent II-I5, 16-20 and $21-25$ years at the rate of $2(5 \%)$ each. Hence $23 \%$ had qualified for this degree in the last six years and were fairly new ILS professionals. 4 (10\%) held positions at the level of Principal Librarian, 3 respondents (8\%) were Deputy University Librarians, and another 3 Subject Librarians. At the other end of the hierarchy were 3 working as Library Assistants or Internship Librarians. These ranks confirm that the Honours graduates tend to move into middle to upper middle management positions and this has implications for their education and training, for instance, with regard to modules in management.

Respondents' duties

Respondents were asked to list and rank the 5 most important duties which they performed in the position described. Rated at most important or important were cataloguing and classification (8), management of staff (7), user education (4), research (3) administration, planning, ICT applications (as in library automation), reference work and teaching (2). Budgeting, acquisitions, Information Management, supervision, collection development, Selective Dissemination of Information (SDI), and shelf reading were all rated I. Some of these duties appear again below rated at average to least important but listed among the 5 areas.

Ranked first as average to least important was acquisitions (8), followed by various user services as in "hands on" assistance to users (4), marketing, user education, budgeting, collection development and participating in professional associations (3). At 2 were cataloguing and classification, database management, information management, circulation and policy. Rated at I were project management, supervision, reference work, shelf reading, staff training, report writing, administration, and SDI. The variety of positions held by the respondents suggests the difficulty of ranking these items.

Ratings of modules, delivery methods and assessment methods

In this section the ratings of modules, delivery and assessment methods are described.

Ratings of modules ${ }^{2}$

Respondents currently employed in information supplying agencies were asked to list and rank the 5 modules completed as part of their Honours programme. The criterion for ranking was the extent to which the module had prepared them for their current position. Since the early 1990s Research Methods and Information Management have been compulsory modules, hence they are mentioned by most of the more recent alumni. There is also some overlap between modules, in that specialist modules such as Children's Books used to be part of a more general Readership or User Studies module. The ratings are split between Table I: Modules rated most useful and useful and Table 2: Modules of average use, less useful and least useful. The same module may appear in either table. 
Table I Modules rated most useful and useful

\begin{tabular}{|c|c|c|}
\hline Module & No. & Why useful \\
\hline Management & 14 & $\begin{array}{l}\text { For decision making eg best way to provide information, for change } \\
\text { management, organising staff, teamwork and understanding organisational } \\
\text { environment. Theory underpins practice. Module tailored to work } \\
\text { situation. }\end{array}$ \\
\hline Information Management & 10 & $\begin{array}{l}\text { Introduction to ICT world, informs timesaving search strategies, very } \\
\text { useful for classification of records and documents work, decisions about } \\
\text { data processing programme, planning ICT development. Preparation for } \\
\text { the direction libraries are moving in. }\end{array}$ \\
\hline User Studies & 5 & $\begin{array}{l}\text { Important for decision-making about data processing programmes; finding } \\
\text { out more about how people need and find and use their information. } \\
\text { important for serving educationally disadvantaged users. Most enjoyable. }\end{array}$ \\
\hline $\begin{array}{l}\text { Bibliography, Cataloguing and } \\
\text { Classification }\end{array}$ & 2 & \\
\hline $\begin{array}{l}\text { Children's Books, Comparative and } \\
\text { Development Librarianship, Indexing } \\
\text { and Essay projects, Philosophy/Ethics }\end{array}$ & 1 & \\
\hline
\end{tabular}

Management scores high both as a duty in the current position and as a module rated most useful and useful by those still in an ILS agency. It rates marginally higher than Information Management as a module. Cataloguing and Classification, which were rated highest as important duties in the current position, scored two as a most useful or useful module. This module is no longer taught as a separate entity at Honours level but is subsumed within Information Management. Both Management and Information Management score higher as most useful and useful modules than the more specialist modules which tend to be seen to lack relevance in a current post. Hart $(2002: 32,35)$, based at the University of the Western Cape, laments the demise of Children's Literature modules and poor enrollment for those that are available. She asks where ILS graduates who are to work in public libraries are to acquire this expertise and links the discussion to the critical need for reading skills in South African learners.

The next table gives the ratings for modules considered of average use, less useful and least useful. As was to be expected there is some overlap with Table I. In this table there is an indication that modules rated here had been useful in prior posts.

Table 2 Modules rated of average use, less useful and least useful

\begin{tabular}{lll}
\hline $\begin{array}{l}\text { Module } \\
\text { No. }\end{array}$ & Why average, less useful or least useful \\
\hline $\begin{array}{l}\text { Readership/User Studies } \\
\text { Research Methods }\end{array}$ & I & $\begin{array}{l}\text { Useful as tailored to work situation. Current position doesn't involve planning as } \\
\text { previous post in schools did, also don't deal with users, don't use knowledge of } \\
\text { Useful for understanding students' research. Don't conduct much research at all } \\
\text { now. }\end{array}$ \\
$\begin{array}{l}\text { Children's Books } \\
\begin{array}{l}\text { Philosophy/Ethics } \\
\text { Long essay }\end{array}\end{array}$ & 4 & $\begin{array}{l}\text { Useful, enjoyed. Not used at present as not working with children } \\
\text { Stimulating intellectually, useful background about why being a librarian is positive } \\
\text { but not relevant to current position. }\end{array}$ \\
$\begin{array}{l}\text { Management } \\
\text { Bibliography }\end{array}$ & 4 & Not using skills at present but will for new project (I response). \\
$\begin{array}{l}\text { Information Management } \\
\text { Cataloguing and Classification, } \\
\text { Indexing, Intellectual Freedom, } \\
\text { Libraries and Literacy, School } \\
\text { Librarianship }\end{array}$ & 3 & 2
\end{tabular}


Readership/User Studies also embraces aspects of acquisitions, user assistance and user education and collection development, rated mid to low as current duties. Research was rated moderately high as a duty in the current positions for those still employed in ILS but Research Methods is located among these lower module ratings. This is notable in view of its being a compulsory module and its ranking first as an area for emphasis in the future below.

\section{Delivery methods}

Those still in information supplying agencies were asked to rank various study related activities for their contribution to their understanding of the modules studied (more than one response was possible). Appropriately the highest ranked response was for reading books and journal articles at $68(81 \%)$. Concerning class discussions (rated at 56, 67\%) as an activity, a respondent remarked that these were often inconclusive or repetitive, a problem also identified by teaching staff. In latter years, with different school leaving routes being used and with recognition of the diversity of student populations, staff have been encouraged to employ a more structured approach to discussions and to teach actively in seminar situations rather than to rely on students' reports of self study activities. Student presentations are synthesised to maximise benefit. Consultation with lecturers or other advisers was rated at 53 (63\%).

\section{Assessment methods}

Of a possible full round of ratings at the highest level of 6 , the approaches to the assessment of students' work scored as follows, with the higher scores indicating a more positive rating. 21 respondents answered this question; hence again the base is 6 times this number. Notable is the high value placed on formative assessment and particularly staff and student interaction such as comment in class discussions $(92,73 \%)$ consultations $(90,71 \%)$ and feedback from assignments $(86$, $68 \%)$. Placed last were knowing the assessment criteria (73, 58\%) and examinations $(61,48 \%)$.

Research activity and further study since completing B.Bibl. Honours

This section presents the findings of the survey on whether or not the respondents had undertaken research and/or further study since completing the B.Bibl. Honours.

Research activity since completing the B.Bibl. Honours

As the first of the higher degrees in ILS the B.Bibl. Honours degree aims to build research capacity in students with, for instance, Advanced Research Methods. The entire base of 40 respondents was asked if they had done research since completing Honours and $2 \mathrm{I}$ (53\%) had. Of the respondents 3 gave no further details and the remaining 17 responded as follows with more than one example being possible. $10(25 \%)$ responded that the research was part of a formal programme with 4 Master's by full dissertation, 3 course work Master's in Information Studies and I attempted Master's (unspecified). Another 2 responses related to a Doctorate in Education on Outcomes Based Education (OBE), and a Master's in Business Administration (MBA). There were 9 (23\%) responses that research formed part of their job, with 3 saying it was carried out as a lecturer, part of teaching research methods or working with research students.

Further study since the completion of the B.Bibl. Honours

Of the 40 respondents, 30 (75\%) had studied further since Honours. More than one response was possible for each respondent. 21 (53\%) had proceeded to a Master's degree. Notably 19 had completed with 2 being in the process of completing. II alumni had completed the UN course work Master's in Information Studies (MIS - which commenced in 1994). The majority of these were still in information supplying agencies. 8 had completed the full dissertation, either the M.Bibl or MIS at UN. I alumnus completed an M.ILS in Michigan in 1994 and another was doing a MBA with a UK based tertiary institution.

General suggestions about improving the programme

All 40 respondents were asked how the programme could be improved with more than one response per respondent being possible. There were $5 \mathrm{I}$ responses with the highest total for those who did not suggest changes or said no change was needed and then secondly for those who did not know. Thereafter the answers run through a variety of suggestions.

The indication overall is for more research emphasis, more ICT but also for information needs assessment and theory on management styles. More integration of theory with practice was required. One module which reflects this integration is dedicated to User Studies, taught since the mid 1990s. This module, which has a strong emphasis on critiquing the research methodologies used in needs assessment, serves as an introduction to research methods and also shows how research methods are applied in specific instances according to the characteristics of users and the nature of the enquiry.

Specific areas for further education and training

30 respondents answered this question with more than I response being possible per respondent and there were 10 non responses. Again ICTs scored high as an area for more emphasis, followed by Management but also by the development and community information aspects. There were suggestions about the economic aspects of ILS from the perspectives of both for profit and not for profit enterprises. Information literacy and user education and again, research 
methods, were addressed. 2 respondents who were no longer working in information agencies commented that the Programme had been responsive to change, giving the examples of ICTs and the "less developed" context.

Table 3 Areas for improvement

\begin{tabular}{|c|c|c|c|}
\hline Area & No. & $\%$ & Comments \\
\hline None & 11 & 28 & Fine as is - has got stronger over the years. \\
\hline Don't know & 8 & 20 & $\begin{array}{l}\text { Not in touch with recent changes; very stimulating then } \\
\text { and major growth period; very enjoyable. }\end{array}$ \\
\hline More research emphasis & 7 & 18 & $\begin{array}{l}\text { Make mini-thesis compulsory; more on critiquing } \\
\text { methodologies in fields unfamiliar to student; basic module } \\
\text { on research methods. }\end{array}$ \\
\hline More ICT & 5 & 13 & $\begin{array}{l}\text { Advanced ICT eg e-documents management; more on- } \\
\text { line searching. }\end{array}$ \\
\hline Integration of theory and practice & 4 & 10 & eg in Information Management and Research Methods \\
\hline $\begin{array}{l}\text { Needs assessment (of this sort), } \\
\text { More emphasis on specializing and } \\
\text { management styles, Group }\end{array}$ & & & \\
\hline discussions & 2 & 5 & \\
\hline $\begin{array}{l}\text { Continue emphasis on current } \\
\text { trends, for SA conditions Training } \\
\text { for user education Rural } \\
\text { librarianship, Advocacy, } \\
\text { Presentation skills, Publishing, } \\
\text { Career guidance in related fields, } \\
\text { Advertising, Marketing }\end{array}$ & 1 & 3 & \\
\hline
\end{tabular}

\section{Discussions and conclusion}

In this section the findings of the study are discussed in relation to the objectives of the study and issues from the literature. Finally a conclusion is drawn.

\section{Discussions}

The objectives of the study were based on the Programme outcomes. The findings of the study are presented below in relation to these outcomes. The survey supported the following findings:

- that the programme had broadly achieved its anticipated outcomes in further preparing the students for the workplace. Alumni feedback tended to confirm current offerings or to suggest modules that had been introduced since their graduation from the programme. Useful emphases are suggested, for instance, the ratings of modules showed that Management and Information Management scored higher as most useful and useful modules than the more specialist modules that tended to be seen to lack relevance in the current post.

- With regard to research endeavour : $53 \%$ of the alumni had undertaken research since completing the programme and over $52 \%$ of the alumni had proceeded to a Master's degree mainly via the course work route. The majority had completed the degree successfully. $75 \%$ had engaged in further study of some sort.

- Views on delivery modes suggested the importance of adequate book and journal holdings as self study involving these sources scored highest in terms of contributing to alumni's understanding of their modules. The current practice of more structured sessions was endorsed.

- Comment from staff was considered important for feedback on assessment and formative assessment was valued.

- There is need for a structured programme of continuing education offerings. This is in harmony with current emphases on lifelong learning and the Skills Development Act (97 of 1998) that endorses the need to make further education and training possible for employees.

In the light of these findings it can be concluded that the study achieved its aims. The survey revealed the extent to which the Programme had achieved its outcomes in the eyes of the alumni.

Before the feedback from this survey various changes had been made to the UN ILS curriculum in response to issues raised in the literature, developments in the services employing UN ILS graduates, and student demand. Staff have sought to balance the demand for the ICTs and Information Management with the user-based approaches and the need for integrating theory, and the inculcating of critical and analytical skills with practice. This direction supports Snyman's analysis of the requirements of the job market (2000). 
In addition with regard to the UN Programme, from 2000 to 2002:

- The existing module in Information Management was merged with an experimental module on Information Systems: Analysis and Design thus refashioning Information Management tomake it more generic.

- Records and Archives Management and Web Based Information Systems were introduced, as was Knowledge Managementwith a human-centred focus. The Web-based Information Systems module equips students with a high level of ICT knowledge and skills. The Knowledge Management module focuses on the need to explore human-centred issues such as sensemaking and cognitive mapping (Cecez-Kecmanovic and Dalmaris 2000) on the one hand, and the use of ICTson the other.

At the same time a greater focus on ICTs has been provided in the UN ILS Programme more generally. An undergraduate module in Internet Expertise will be offered in 2004.

Recent developments in the curriculum include:

- a compulsory generic School module in Advanced Research Methods covering both qualitative and quantitative research methods with foci on the History and Philosophy, and Politics and Ethics, of Social Research.

- a more generic option in the records management aspects of Records and Archives Management in addition to an archives option to cater for increasing numbers of Policy and Development students. As prospective government officials these students will be subject to the Promotion of Access to Information Act (2 of 2000) that enshrines the constitutional right of citizens to access information held by the state and other parties that is required for the exercise and protection of civil rights. The Policy and Development Programme in turn offers part of a module on Policy

Evaluation and Implementation in the core module of the course work Masters in ILS.

The UN programme's success in achieving a balance between a human-centred approach and the use of Information and Communication Technologies, in combining theory with practice and inculcating critical and analytical skills needs to be assessed more thoroughly and over a longer period of time. Generally the Programme has achieved a balance. Problems, however, have arisen concerning the provision of a variety of ICT related modules in that lower student numbers prevent good group dynamics in the specialist modules.

\section{Conclusion}

In conclusion, the survey fulfilled its aims in revealing the extent to which, in the eyes of the alumni, the Programme has attained its outcomes. To some extent a balance has been achieved between the various considerations outlined in the literature. The findings of the study are useful for programme review for this particular ILS education programme and hopefully for others. This modest study has provided the base for other tracer studies for the Programme and has served to inform policy for the B.Bibl. Honours programme in particular.

\section{Acknowledgments}

Thanks go to the UN Research Fund, the alumni, Surie Balloo for data reduction, my colleagues for in-house peer review, to Barbara Gentil for editing and to three anonymous referees for their critical comment.

\section{References}

Bell, F. 1998. The Department of Information Studies, University of Natal: its role in Education for Librarianship in South Africa, 1975-1994. Master's Thesis. Pietermaritzburg: University of Natal, Information Studies.

Dervin, B. 1992. From the mind's eye of the "user": the sensemaking qualitative methodology. In J.D. Glazier and R. Powell (eds.) Qualitative research in information management. Englewood: Libraries Unlimited:61-84.

Dervin, B. 1994. Information<>democracy: an examination of underlying assumptions. Journal of American Society for Information Science 45:369-85.

Cecez-Kecmanovic, D. and P. Dalmaris. 2000. Knowledge mapping as sensemaking in organizations. Proceedings of the Australian Conference on Information Systems, ACIS, 8-10 December, 2000, Brisbane. [Online] Available www.businesszone.co.uk/item/83980 Viewed 19 August 2003.

Goulding, A., Bromham, B., Hannabuss, S. and D. Cramer. 1999. Likely to succeed: attitudes and aptitudes for an effective information profession in the $21^{\text {st }}$ century. Boston Spa: Library and Information Commission.

Hart, G. 2002. The African Renaissance and children's literature: is South African librarianship abdicating its role? South African journal of libraries and information science 68(I):29-38.

Kaniki, A.M. 1994. Specialist training for information provision to rural communities in South Africa. Innovation 9:35-42.

Manaka, S. 1999. Continuing professional education in South Africa. In: M.Wise (ed.) Education for librarianship and information science in Africa. Uppsala: Uppsala University Press/IFLA: I99-21I.

Martyn, J., P.Vickers and M. Feeney (eds.) 1990. Information UK. 2000. London: British Library/Bowker-Saur.

Mhlongo, M. 1998. The Preparedness of technikon-trained Library and Information Science diplomates for the work situation: an evaluative study. Master's Thesis. Pietermaritzburg: University of Natal, Information Studies.

Muddiman, D. 1994. Innovation ... or instrumental drift? The "New Vocationalism" and information and library education in the United Kingdom. Education for information 12:259-70.

Ocholla, D. 2000. Training for Library and Information Studies: a comparative overview of LIS education in Africa. Education for information 18:33-52. 
Ocholla, D. 200I. Curriculum response to a changing national and international information environment: theoretical and methodological paradigms on review and revision. Education for information 19:143-67.

Orna, E. 1999. Practical information policies. $2^{\text {nd }}$ ed. Aldershot: Gower.

Parker, B. 2002. The segmentation of Higher Education: the case of teacher education. Paper presented at a Graduate Student and Staff Seminar Programme (GRASSP) seminar, May, School of Human and Social Studies, University of Natal, Pietermaritzburg.

Remenyi, D., T. White and M.S. Smith. 1977. Information systems management: the need for a postmodern approach. International journal of information management 17:421-35.

Snowden, D. 2002. Complex acts of knowing: paradox and descriptive self-awareness. Special Edition, Journal of Knowledge Management 6(2): I-14.

Snowden, D. 2003. Paper on the Cynefin Centre for Organisational Complexity, presented at the Colloquium on Knowledge Dynamics, the Knowledge Economy and Africa, Centre for Knowledge Dynamics and Decision Making, University of Stellenbosch, Stellenbosch, 28-29 ${ }^{\text {th }}$ July.

Snyman, R. 2000. Employment patterns for information professionals in South Africa. Paper delivered to the Library and Information Association of South Africa Conference, Durban, 22-26 ${ }^{\text {th }}$ September

Underwood, P.G. and M.C. Nassimbeni. 1999. "We shall all be changed": professional development and training in the Republic of South Africa. In: M.Wise (ed.) Education for librarianship and information science in Africa. Uppsala: Uppsala University Press/IFLA: 179-98.

University of Natal. Department of Information Studies. 1994. Mission Statement. Pietermaritzburg: Department.

University of Natal. Faculty of Human and Management Sciences. 2002. Handbook. Pietermaritzburg: Faculty.

\section{Endnotes}

I. Copy of the survey is available from the author.

2. Module content from the University of Natal handbook (2002).

Information Management Theories, principles and issues of information storage and retrieval; information management and its relation to library science, archives, records and knowledge management; computer systems, telecommunications, and the Internet and their applications to information storage and retrieval; information theory, standards, vocabulary control, indexing, expert systems, e-publishing and cooperative information systems and services.

Knowledge Management Defining and understanding knowledge management, the key concepts and relevant theories; justifying knowledge management; relationships between data, information and knowledge, and their management; identifying skills for the knowledge age; role of technology in knowledge sharing; principles of knowledge management, i.e. making knowledge visible; building knowledge intensity; building knowledge infrastructure; developing a knowledge culture and sharing knowledge; value-adding processes.

Web-Based Information Systems History of the Internet and the World Wide Web (Web); Web architecture, site design and development; content development and management; development tools; standards; the W W W Consortium (W3C); browsers; HTML; XML; JavaScripts; metadata; styles sheets; information gateways; evaluating systems; providing access to Web content on the Internet, intranets, extranets and portals. Cases studies of Web-based information systems. 